\title{
Towards effective culvert design: monitoring seasonal use and behavior by Mediterranean mesocarnivores
}

\author{
Ana Marta Serronha • Ana Rita Amaro Mateus • \\ Finn Eaton • Margarida Santos-Reis • Clara Grilo
}

\begin{abstract}
Drainage culverts are known to be used by a diverse number of species. To date, most studies looking at culvert usage have been restricted to the dry season. This seasonal bias has limited our understanding of how different species respond to culverts and, consequently, our ability to find effective ways to promote the use of culverts as aids to species movement. The main goal of this study was to examine the role of highway culverts for mesocarnivores throughout the year. We addressed (1) the seasonality of culvert use, (2) the relative importance of culvert structure, highway features, and surrounding landscape on culvert use, (3) the influence of the water depth
\end{abstract}

A. M. Serronha - A. R. A. Mateus - M. Santos-Reis •

C. Grilo

Centro de Biologia Ambiental/Departamento de Biologia

Animal, Faculdade de Ciências

Universidade de Lisboa, C2 $5^{\circ}$,

1749-016 Lisbon, Portugal

A. M. Serronha $(\bowtie)$

CIBIO, Centro de Investigação em Biodiversidade e

Recursos Genéticos, InBIO Laboratório Associado,

Universidade do Porto,

Campus Agrário de Vairão,

4485-661 Vairão, Portugal

e-mail: anaserronha@cibio.up.pt

\author{
A. R. A. Mateus \\ Instituto Gulbenkian de Ciência, \\ Rua da Quinta Grande 6, \\ 2780 Oeiras, Portugal
}

and cover on culvert use, and (4) the effect of culvert structure on individual behavior. Fifteen culverts were monitored along 2 highways in southern Portugal using video-surveillance cameras and marble dust for 10 consecutive days per season. We used generalized linear mixed models to determine which factors most affected the culvert use and behavior by mesocarnivores. Our results highlight the effect of seasonality and water on culvert use. Culvert use was positively related with species activity throughout the year. All species (except otters (Lutra lutra)) were less likely to use culverts that contained water more than $3 \mathrm{~cm}$ deep or covering more than $70 \%$ of the culvert

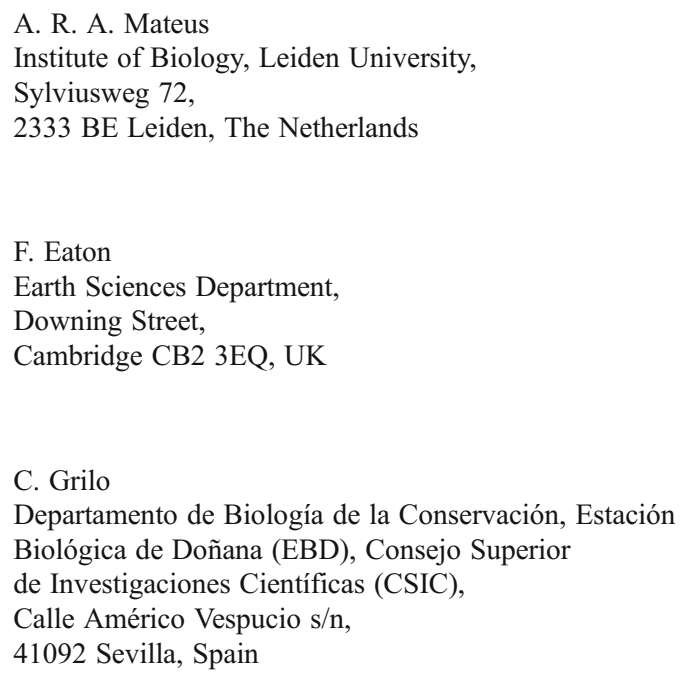


base. Based on our results, future surveys and culvert retrofit design should address (1) the importance of seasonality in the interpretation of results and (2) the complementarity of culvertspecific features (water, ledges, and naturalization).

Keywords Carnivore conservation · Road mitigation measures · Crossing structures · Video-surveillance

\section{Introduction}

Road networks have grown over the last few decades in response to increasing human demands (Forman et al. 2003) and have been described as one of the largest threats to biodiversity (e.g., Fahrig and Rytwinski 2009; van der Ree et al. 2011). They can act as barriers to animal movement, either through direct mortality due to vehicle strike or by the promotion of avoidance behaviors (Jaeger et al. 2005; Grilo et al. 2009). In the long term, roads may lead to irreversible ecological consequences, such as reduced gene flow between fragmented populations (e.g., Epps et al. 2005) which is known to contribute to the decrease in genetic variability and increase the risk of local extinction by stochastic effects (Riley et al. 2006).

In order to mitigate such effects, solutions have been sought to allow animals to cross roads safely. One solution has been the use of drainage culverts as aids to animal movement (e.g., Taylor and Goldlingay 2009; van der Ree et al. 2009). These structures pass perpendicularly under roads and are widespread throughout the road network. Their main function is to allow water to drain from the surrounding area to prevent flooding and maintain the natural flow of local streams (Rossell and Velasco 2001).

It is generally agreed that drainage culverts are regularly used by mesocarnivores (Yanes et al. 1995; Rodriguez et al. 1996; Clevenger et al. 2001; Cain et al. 2003; $\mathrm{Ng}$ et al. 2004). Previous research indicates that the shape of culverts (Mata et al. 2005, 2008), as well the availability of cover near culvert entrances (Rodriguez et al. 1996; Ascensão and Mira 2006; Grilo et al. 2008), plays an important role in how culverts are used. As the most widely used survey technique is marble dust, or other similar tracking substrates that are washed away with rain, previous studies were generally restricted to the dry season or were interrupted during rainy periods (e.g., Yanes et al. 1995; Rodriguez et al. 1996; Mata et al. 2005, 2009; Ascensão and Mira 2006; Grilo et al. 2008). This has limited our knowledge on how to design culverts so that they can best promote animal movement. To date, there have been no documented studies that have focused on how carnivores use culverts throughout the year or on how the presence of water within culverts may affect animal behavior and culvert usage.

One method that allows for the evaluation of how water affects the extent culverts are used by carnivores to cross roads is video-surveillance (Stewart et al. 1997; Mateus et al. 2011). This method also has the advantage of being able to record an animal's behavior towards the culvert itself (see Hardy et al. 2003; Dodd et al. 2007), which can yield valuable insights regarding culvert design as a road mitigation measure.

In this study we wanted to address (1) the effect of season on culvert use; (2) the relative importance of culvert and highway features and of the surrounding landscape on culvert use, irrespective of season; (3) the influence of water depth and cover at culvert entrances on culvert use, and also (4) the effect of culvert structural features on individual behavior. We separated the analysis to clarify the role of each group of features on culvert use, taking into account the random variation in space (culverts surveyed) and/or time (season).

\section{Methods}

Data collection

Fifteen drainage culverts were surveyed along 2 highways (A2 and A6) in Alentejo, southern Portugal (Fig. 1). The average distance between culverts was $2 \mathrm{~km}$ to minimize the effects of spatial autocorrelation and assure independence of observations (Guisan and Zimmermann 2000). This value corresponds to the average diameter of medium-sized carnivore home range (Cavalini and Lovari 1994; Palomares and Delibes 1994; Rosalino et al. 2004; Ruiz-Olmo et al. 2001; Santos-Reis et al. 2004). The majority of culverts used in this study were located in cork oak (Quercus suber) woodlands, the dominant landscape in the region, and their choice was based on logistical 

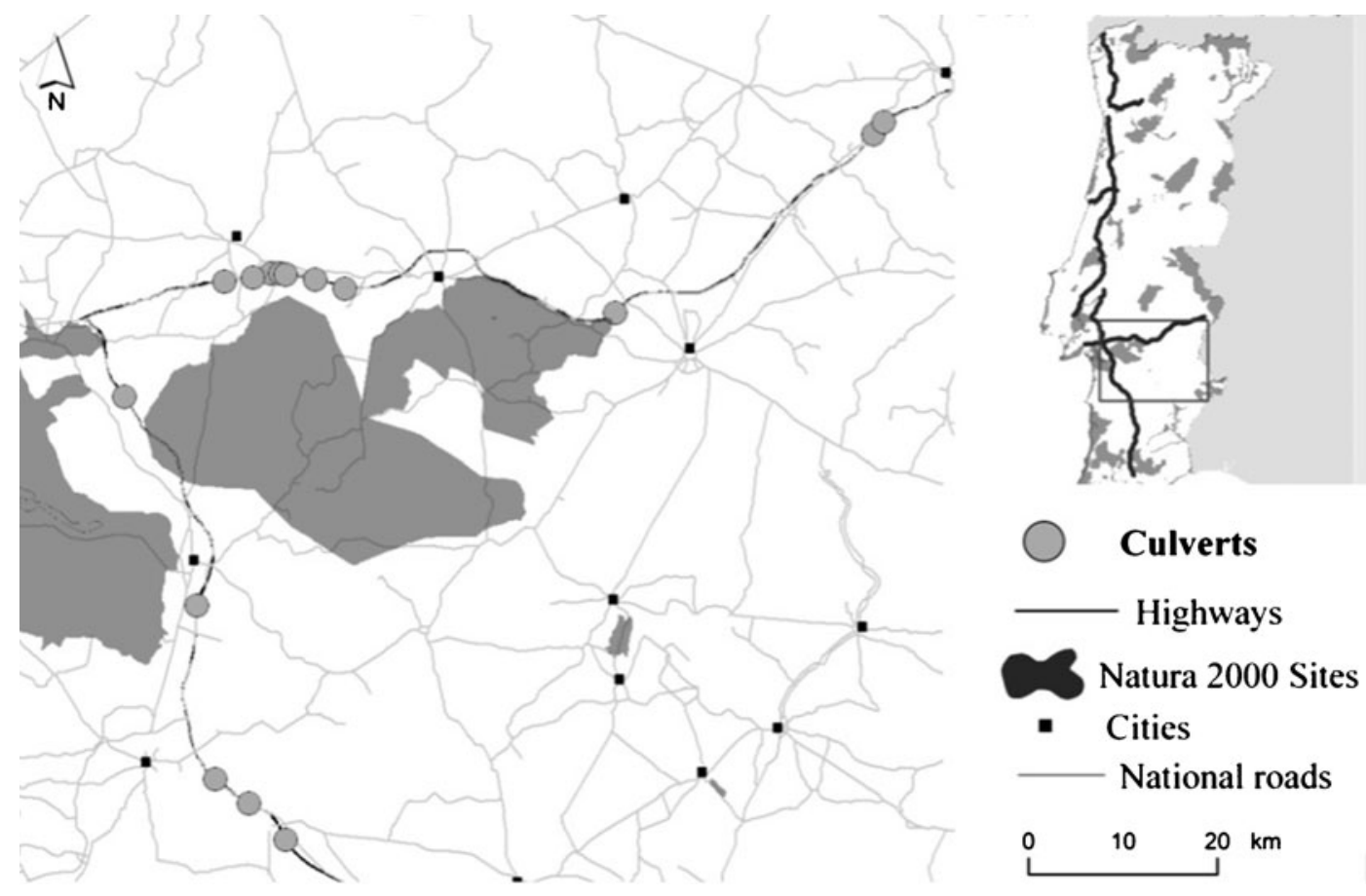

Highways
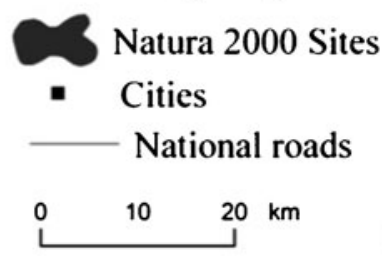

Fig. 1 Study area with the location of the culverts surveyed

criteria such as security and a low probability of vandalism.

Culverts were surveyed throughout 1 year (from the autumn of 2005 to the summer of 2006) using videosurveillance systems to visualize animals approaching/ crossing and marble dust to record their tracks. Each culvert was surveyed for 10 consecutive days per season (autumn, winter, spring, and summer), resulting in a total of 40 days of surveillance. Videosurveillance provided a continuous record of the nighttime activity, from dusk till dawn, a total of $14 \mathrm{~h}$ of nighttime surveillance. This decision was based on the fact that, with the exception of the Egyptian mongoose Herpestes ichneumon (Palomares and Delibes 1992), Mediterranean carnivores exhibit nocturnal activity (Blanco 1998). These surveillance systems were hidden near the entrances of each culvert. Two pairs of one camera and an infrared illuminator pair with 56 automatic-activation infrared light-emitting diode (YIL-56DS), and an infrared light capacity of up to $3 \mathrm{~m}$, were respectively positioned to film the inside and the outside of each culvert (see also Mateus et al. 2011). For every event recorded, we registered the animal's species, the direction of the individual's movement, and the type of crossing (successful or attempted). A successful crossing was defined when an animal passed through a culvert and did not pass back through the same opening within $2 \mathrm{~min}$; this helped to avoid multiple counts of any animal that stayed near the culverts' entrance. A crossing was considered to be "attempted" when an animal entered the culvert but returned within 2 min by the same entrance or when it approached a culvert but did not enter.

Each crossing was also described on the basis of the individual's behavior towards the culvert. Reluctant behavior in relation to culverts was defined when any animal took more than $4 \mathrm{~s}$ to cross the distance between the two cameras (approximately $5 \mathrm{~m}$ ) as it was entering or leaving the culvert.

Data analysis

\section{Effects of seasonality on culvert use}

A univariate analysis was performed to examine the relationship between culverts use with each season using generalized linear mixed models (GLMM) with Poisson distribution and log link function for each species. The number of successful crossings was the 
response variable and culvert ID was the random effect to avoid pseudoreplication among culverts (Bolker et al. 2009). When residuals indicated overdispersion, the data was refitted with a quasi-Poisson model.

\section{Effect of culvert, highway, and surrounding landscape features on culverts use}

Each drainage culvert was characterized by using a list of 15 independent variables incorporating culvert-, highway-, and landscape-related features (Table 1). Culvert-related features included structural features such as culvert width, length, area, openness, and shape. These features have been shown to have an effect on how different vertebrate species utilize culverts (e.g., Clevenger et al. 2001; Mata et al. 2008). Culverts were additionally characterized in terms of internal presence of water, presence of vegetation at the entrances within a 50-m buffer around the culvert (a reasonable distance to measure in the field), and distance from highway pavement.

Road-related features included daily average traffic volume and number of existing passages (overpasses, underpasses, and culverts) in a 500$\mathrm{m}$ buffer around each culvert (source: BrisaAuto-estradas de Portugal S.A.). The surrounding landscape at each entrance was characterized within a radius of $500 \mathrm{~m}$ on the basis of the percentage of land covered by forest (oak woodlands and pine woodlands), open areas, and understory, the distance to water sources, and the orientation of riparian vegetation in relation to the culvert axis.

Similar to the previous analyses, a five speciesspecific GLMM with Poisson distribution and log

Table 1 Summary of culvert-, highway-, and landscape-related features including designation, definition, and range

\begin{tabular}{|c|c|c|}
\hline Variables & Definition & Range \\
\hline \multicolumn{3}{|l|}{ Culvert-related features } \\
\hline Culvert width & Culvert width (m) & $1-4$ \\
\hline Culvert length & Culvert length (m) & $1-4$ \\
\hline Culvert area & Culvert section area $\left(\mathrm{m}^{2}\right)$ & $0.79-9$ \\
\hline Openness & Width $\times$ height $/$ length & $0.014-0.209$ \\
\hline Shape & 1 - circular; 2 - square & $1 ; 2$ \\
\hline Water inside the culvert & 0 - absence; 1 - presence (if cover the entire culvert base) & $0 ; 1$ \\
\hline Vegetation at the entrance & 0 -absence; 1 - one culvert side; 2 - on both culvert sides ${ }^{\mathrm{a}}$ & $0 ; 1 ; 2$ \\
\hline Distance to highway & Distance from the culvert to the travel lane of the highway $(\mathrm{m})$ & $9-30$ \\
\hline \multicolumn{3}{|l|}{ Highway-related features } \\
\hline Traffic volume & Mean 2005/2006 average daily traffic volume (vehicles/day) & $2,227-12,096$ \\
\hline Number of crossing structures & Number of crossing structures ${ }^{b}$ & $2-6$ \\
\hline \multicolumn{3}{|l|}{ Landscape-related features } \\
\hline Forest & Oak or pine woodlands $(\%)^{\mathrm{b}}$ & $20-100$ \\
\hline Open areas & Extensive agriculture $^{\mathrm{b}}$ & $0-60$ \\
\hline Understory cover & Shrub cover ${ }^{b}$ & $0-60$ \\
\hline Distance to water sources & Distance to the nearest streams, ponds or lakes (m) & $510-18,695$ \\
\hline Orientation of riparian vegetation & $\begin{array}{l}0 \text { - absence; } 1 \text { - parallel on both culvert sides; } 2 \text { - parallel on } \\
\text { one side and perpendicular on the other; } 3 \text { - perpendicular } \\
\text { on both culvert sides }\end{array}$ & $0-3$ \\
\hline \multicolumn{3}{|l|}{ Water presence ${ }^{\mathrm{c}}$} \\
\hline Water depth & Water depth $(\mathrm{cm})$ (if cover the entire culvert base) & $0-90$ \\
\hline Water cover & Percentage of water cover on the culvert base & $0-100$ \\
\hline
\end{tabular}

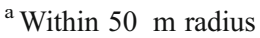

${ }^{\mathrm{b}}$ Within 500 m radius

${ }^{\mathrm{c}}$ Used only for univariate analysis regarding water depth and cover
} 
link function was selected to assess the culvert-, highway-, and landscape-related features that are thought to influence culvert use. The number of successful crossings was used as the response variable (Zuur et al. 2009). Culvert ID and season were used as random effects to avoid pseudoreplication (Bolker et al. 2009). Prior to this analysis, the association between culvert features was investigated using Spearman's rank correlation in order to reduce the effects of multicollinearity. For any pair of independent variables that resulted in an $r \geq 0.50$ (with $p<0.05$ ), the variable with the smallest biological meaning was removed. The candidate models for GLMM analysis were designed using four sets of variables corresponding to the following hypotheses: (1) culvert structure affects the use of culverts, (2) crossing events are related to highway features, (3) characteristics of the surrounding landscape explain the crossings, and (4) the interaction of the best previous models explains the crossings. Because we detected overdispersion in our residuals, standard errors were corrected using a quasi-Poisson model. In this case, the Akaike's information criterion (AIC) is not defined; thus, we had to compare two models $M_{1}$ (full model) and $M_{2}$ (nested model) using the $F$ test statistic. To do so, a full model was initially used, nonsignificant terms were then removed (nested model), and this process was repeated until a model containing only significant variables was produced.

Additionally, using a GLMM univariate analysis for each species, predictions were made as to how water cover (in percent) and depth inside the culvert (Table 1) would affect the likelihood of culvert use by carnivores during the wet seasons (autumn and winter). Culvert ID and season were used as random effects to avoid pseudoreplication.

\section{Species behavior within culverts}

The behavioral attributes (reluctance or nonreluctance) of each individual crossing were also analyzed. The influence of specific culvert structural features (Table 1) on the behavior of animals entering and leaving a culvert was, therefore, examined. This was carried out using five species-specific GLMM with binomial distribution and logit link function for behavior data (reluctant $=0$ and no reluctant $=1$ ) and culverts as random effect.
All statistical tests were performed using the lme4 (Bates et al. 2011) and nmle (Pinheiro et al. 2012) packages in $\mathrm{R}$ version 2.10.1 ( $\mathrm{R}$ Development Core Team 2011).

\section{Results}

Crossing events

A total of 405 successful crossings were recorded. This is equivalent to $0.68 \pm 0.01$ crossings/culvert/day (mean \pm standard deviation). Of these crossings, $42 \%$ was performed by Eurasian badgers (Meles meles), $20 \%$ by stone martens (Martes foina), $20 \%$ by Eurasian otter, $10 \%$ by common genet (Genetta genetta), and $9 \%$ by red fox (Vulpes vulpes). On 60 other occasions, animals approaching the culvert did not effectively cross through the structure, resulting in $67 \%$ of successful crossings for red fox (successful crossings/(successful crossings + crossing attempts)), followed by $87 \%$ for stone marten and genet and $91 \%$ for Eurasian badger and Eurasian otter. None of the other mesocarnivores potentially occurring in the region (e.g., weasel Mustela nivalis, polecat Mustela putorius) approached the surveyed culverts during the study period.

Effects of seasonality on culverts use

Carnivore species exhibited different responses to culverts in each of the four survey seasons (Fig. 2). The univariate analysis show that red fox crossings are positively associated with spring, whereas in summer, culverts were significantly more frequently used by stone marten and genet than in other seasons. The results of this study also showed that, in winter, otters use culverts more often than in other seasons (Table 2).

Effects of culverts and highway features and surrounding landscape on culverts use

The effect of culvert-, highway-, and landscaperelated attributes on culvert use varied among species (Table 3). We observed a number of trends in culvert use exhibited by the study species: (1) the presence of water had the strongest negative influence on culvert use by stone marten and genet; (2) 
Fig. 2 Successful crossing rate in each season and standard deviation

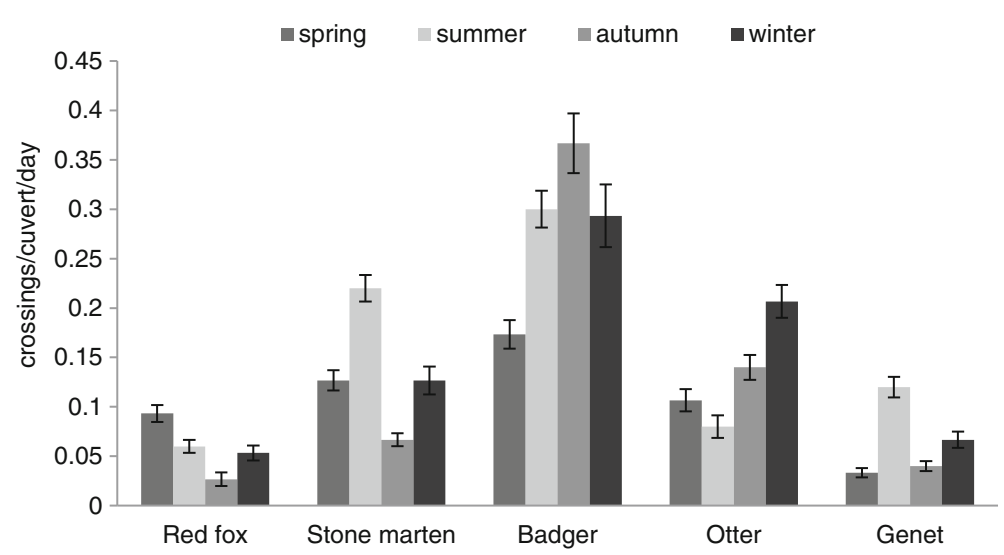

there were few recorded observations of culvert use by red fox when culverts were in open areas; (3) stone marten unexpectedly tended to avoid culverts with vegetation cover at the entrance; and (4) otters tended to cross through culverts with riparian vegetation oriented towards the culvert.

By applying the estimates obtained for the univariate analysis regarding water cover and depth (Appendix), it was observed that all species, apart from otters, are less likely to use a culvert when water depth inside was higher than $3 \mathrm{~cm}$ (Fig. 3a). On the other hand, otter tend to use culverts more often when water reaches $50 \mathrm{~cm}$ in depth. It was also observed that red foxes, stone martens, and genets are less likely to use culverts that are covered internally with more than $70 \%$ water. This finding is inversely true for otters, which respond positively to this factor (Fig. 3b).

Species behavior towards culverts

Red fox and genet were not included in the GLMM analysis as there was lack of data regarding crossings made by these two species. Four
Table 2 Summary of univariate analysis of the relationship between successful crossings and season for each carnivore species (coefficient estimates)

We only show the seasons with AIC $<2$

AIC Akaike's information criterion, $\triangle A I C \mathrm{AIC}_{i}-\min \mathrm{AIC}, W_{i}$ Akaike's weight, $S E$ standard error, $Z$ test significance of the $Z$ test

\begin{tabular}{|c|c|c|c|c|c|c|c|}
\hline Variables & AIC & $\Delta \mathrm{AIC}$ & $W_{i}$ & Estimate & $\mathrm{SE}$ & $Z$ test & Significance \\
\hline \multicolumn{8}{|l|}{ Red fox } \\
\hline Autumn & 77.59 & 0 & 0.398 & -0.949 & 0.545 & -1.742 & 0.081 \\
\hline Spring & 77.85 & 0.26 & 0.350 & 0.693 & 0.354 & 1.959 & 0.050 \\
\hline Null & 79.64 & & & & & & \\
\hline \multicolumn{8}{|c|}{ Stone marten } \\
\hline Autumn & 110.6 & 1.6 & 0.302 & -0.862 & 0.341 & -2.527 & 0.012 \\
\hline Summer & 109 & 0 & 0.671 & 0.724 & 0.228 & 3.172 & 0.002 \\
\hline Null & 116.6 & & & & & & \\
\hline \multicolumn{8}{|l|}{ Badger } \\
\hline Spring & 134.4 & 0 & 0.398 & -0.613 & 0.214 & -2.871 & 0.004 \\
\hline Null & 141.9 & & & & & & \\
\hline \multicolumn{8}{|l|}{ Otter } \\
\hline Winter & 101.7 & 0 & 0.709 & 0.641 & 0.231 & 2.773 & 0.006 \\
\hline Null & 107 & & & & & & \\
\hline \multicolumn{8}{|l|}{ Genet } \\
\hline Summer & 90.83 & 0 & 0.826 & 0.944 & 0.329 & 2.873 & 0.004 \\
\hline Null & 96.98 & & & & & & \\
\hline
\end{tabular}


Table 3 Quasi-Poisson models for each species (coefficient estimates)

$S E$ standard error, $Z$ test significance of the $Z$ test

\begin{tabular}{lrrrc}
\hline Variables & Estimate & SE & $Z$ value & Significance \\
\hline Red fox & & & & \\
$\quad$ Intercept & -0.476 & 0.326 & -1.460 & 0.144 \\
$\quad$ Open areas & -0.045 & 0.023 & -1.999 & 0.046 \\
Stone marten & & & & \\
$\quad$ Intercept & 0.572 & 0.299 & 1.914 & 0.055 \\
$\quad$ Vegetation at entrance & -0.045 & 0.016 & 25.962 & $<0.001$ \\
$\quad$ Water presence & -1.113 & 0.440 & -2.532 & 0.011 \\
Otter & & & & \\
$\quad$ Intercept & -1.308 & 0.622 & -2.102 & 0.036 \\
$\quad$ Orientation of riparian vegetation & 0.513 & 0.262 & 1.954 & 0.050 \\
$\quad$ Genet & & & & \\
$\quad$ Intercept & -0.243 & 0.277 & -0.877 & 0.380 \\
$\quad$ Water presence & -2.181 & 0.662 & -3.296 & 0.001 \\
\hline
\end{tabular}

culvert structural features explained the behavior of the remaining species when entering and
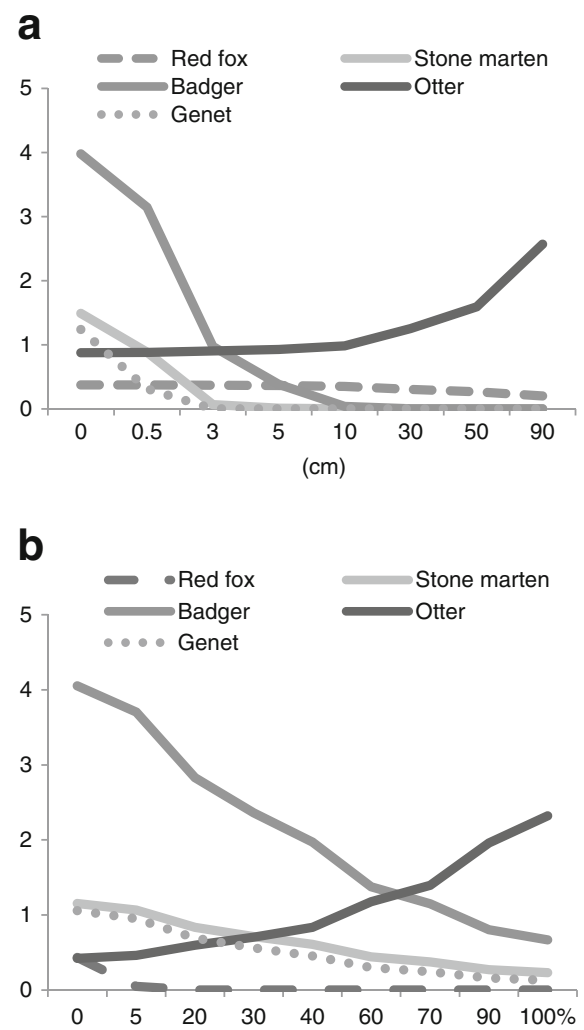

Fig. 3 Number of carnivore crossings per day in culverts obtained from the GLMM Poisson models related with water depth (in centimeters) (a) and percentage of cover (b) leaving a culvert: (1) culvert width, (2) culvert length, (3) water presence, and (4) the presence of vegetation at the entrance of a culvert. However, these features do not fully explain the behavior of badgers when they enter culverts and otters when they leave culverts (Table 4). Stone martens seem to be more reluctant when entering long culverts and when leaving culverts with water. In contrast, no reluctant behavior was observed for badgers leaving culverts with vegetation at their entrances. Otters were also seen to move at higher speeds when they passed through wide culverts.

\section{Discussion}

Several studies have already documented that drainage culverts can be used as crucial tools to improve habitat connectivity and thereby mitigate the barrier effect caused by roads for carnivores in a Mediterranean context (see Yanes et al. 1995; Mata et al. 2008; Grilo et al. 2008). Our results are in accordance with these studies, but go further to highlight the role of seasonality and water presence on culvert use. These results are further supported by our observations of carnivore behavior when entering or leaving drainage culverts. Moreover, we documented that species respond differently to culvert-, road-, and landscape-related attributes. 
Table 4 Summary of univariate analysis of the relationship between reluctance and nonreluctance behaviors with structural culvert features for each carnivore species (coefficient estimates)

\begin{tabular}{|c|c|c|c|c|c|c|c|c|}
\hline \multicolumn{2}{|l|}{ Models } & AIC & $\Delta \mathrm{AIC}$ & AIC weight & Estimate & SE & $Z$ value & Significance \\
\hline \multicolumn{9}{|c|}{ Stone marten } \\
\hline \multirow[t]{3}{*}{ Enter } & Null & 48.99 & 0.38 & 0.05 & & & & \\
\hline & Intercept & & & & 4.372 & 2.555 & 1.711 & 0.087 \\
\hline & Culvert length & 48.61 & 0 & & -0.059 & 0.040 & -1.474 & 0.140 \\
\hline \multirow[t]{3}{*}{ Leave } & Null & 48.99 & 5 & 0.267 & & & & \\
\hline & Intercept & & & & 1.139 & 0.406 & 2.805 & 0.005 \\
\hline & Water presence & 44.02 & 0 & 0.291 & -1.8327 & 1.290 & -1.420 & 0.156 \\
\hline \multicolumn{9}{|l|}{ Badger } \\
\hline \multirow[t]{3}{*}{ Leave } & Null & 53.04 & 0.9 & 0.219 & & & & \\
\hline & Intercept & & & & -2.8585 & 0.648 & -4.411 & 0.000 \\
\hline & Vegetation at the entrance & 52.19 & 0 & 0.334 & 0.2512 & 0.1262 & 1.991 & 0.047 \\
\hline \multicolumn{9}{|l|}{ Otter } \\
\hline \multirow[t]{3}{*}{ Enter } & Null & 46.87 & 2.1 & 0.118 & & & & \\
\hline & Intercept & & & & -1.2468 & 1.0024 & -1.244 & 0.214 \\
\hline & Culvert width & 45.05 & 0.3 & 0.292 & 0.9096 & 0.4431 & 2.053 & 0.040 \\
\hline
\end{tabular}

We only show the variables with AIC lower than the AIC of the null model

$A I C$ Akaike's information criterion, $\triangle A I C \mathrm{AIC}_{i}-\operatorname{minAIC}, W_{i}$ Akaike's weight, $S E$ standard error, $Z$ test significance of the $Z$ test

Not surprisingly, this study shows that simply surveying during dry seasons provides only a partial picture and can lead to biased results regarding species life history traits. Our findings show that the intensity of use of culverts is affected by specific phenological periods. Higher use of culverts is correlated to periods with high levels of activity, such as during mating seasons and times when species have young to feed (Blanco 1998). At these times of behavioral change, individuals tend to increase their rate of movement and enlarge their territories, increasing the likelihood of encountering culverts. For example, stone martens and otters used culverts more regularly during the mating period (summer and winter, respectively). Red foxes used culverts more often in spring, which coincides with their period of final gestation and the feeding of young. These results are supported by the work of Mata et al. (2009), which examined the passages used during summer and winter and found marked seasonality on passages used by red foxes, badgers, and genets. Similarly, previous research has demonstrated that high mortality associated with vehicular collisions involving carnivores is strongly correlated with periods of mating and the feeding of young (Grilo et al. 2009).

The most novel finding from our research is the role of water in the use of culverts by carnivores. All species (except otters) tend to avoid culverts when the internal water depth and the percentage of floor covered by water increases. Our results suggest that only a few centimeters of water $(3 \mathrm{~cm})$ appeared to be enough to discourage animals from crossing through a culvert (Rossell and Velasco 2001). More importantly, water inside culverts seems to act as an effective barrier to stone martens and genets, both forest-dwelling species that selected culverts without water independent of the season. This finding was further supported by the exhibition of reluctant behavior in stone marten when leaving a culvert containing water. In contrast, and as expected in view of the species lifestyle (a semiaquatic species that uses water to move and forage-Kruuk 2006), the presence of water had a positive effect on the use of culverts by otters. We predicted that otters were more likely to use culverts that contain more than $70 \%$ of water cover and $50 \mathrm{~cm}$ of water depth. The method of surveillance used allowed a more robust 
form of data collection on otter behavior towards culverts. However, differences in otter densities could be affecting the different findings among published studies (Ascensão and Mira 2006; Mata et al. 2005, 2008; Grilo et al. 2008).

Besides water, a number of other variables also affected the use of culverts. For example, the orientation of riparian vegetation was positively related to the use of culverts by otters. Although riparian vegetation reflects a constant source of water which is crucial for otter's movement and food availability, these structures are also provide shelter (Prenda and Granado-Lorencio 1996). Otter's behavior towards the entrances of culverts also supports this result: as they moved with higher speed in wider culverts, otters have low confidence in culverts that appear to have less available cover. The absence of natural objects (e.g., vegetation, wood, stones) inside culverts is translated into a low cover availability which decreases the confidence of otters in using culvert as the width increases. In contrast, this study also showed that vegetation at the entrance of a culvert negatively affected the use of that culvert by stone martens. This is an unexpected behavior for a forest-dwelling species because the presence of vegetation should theoretically reduce the mistrust of these animals towards artificial structures, such as culverts, by providing the perception of habitat continuity (Hobbs 1992; Palomares and Delibes 1993; Virgós 2001; Santos-Reis et al. 2004; Matos et al. 2009). In fact, Mata et al. (2005) and Grilo et al. (2008) also found no significant relationship between the presence of vegetation at a culverts' entrance and overall culvert use.

Our study represents the first attempt to analyze the use of culverts by mesocarnivores over different seasons. It is also the first study to examine the behavioral responses exhibited by mesocarnivores when they encounter a culvert. Overall, this study goes on to provide a more complete view of the role culverts play in the lives of mesocarnivores. Thus, there are several issues that should be taken in account when examining the role of these structures in the maintenance of habitat connectivity. Firstly, there is the effect of mesocarnivore activity on the results, meaning that the interpretation of the results should consider the season the survey was conducted in. Furthermore, one important question should be addressed when a survey of this nature is completed: is a low frequency of culvert use related with overall low species activity or with water presence within culverts? If a low frequency of use is related with low activity level, culvert-related factors, such as water content, would have no influence on eventual culvert usage. In the second case, the presence of water in a culvert, we should examine if this lack of culvert use also corresponds to breeding and/or dispersal periods. During these periods, limitation of movement due to avoidance behavior towards culverts may change the demographic structure of populations as it alters genetic exchange (e.g., Row et al. 2007). Another important issue is the diversity of responses of mesocarnivores towards culverts. Previously, Mata et al. (2005) suggested the establishment of differently sized crossing structures to allow complementary use by terrestrial vertebrates. Our findings suggest that the diverse nature of attributes associated to different culverts, i.e., presence/absence of water and presence/absence of vegetation at the entrances, accounts for the wide range of responses towards culverts from different species in the mesocarnivores community. Therefore, as suggested by Bissonette and Adair (2007), a number of culverts, each with a range of characteristics (vegetation plantation at entrance and dry ledges in culverts with water in most part of the year), should be placed within an area similar to the average daily movement distance of mesocarnivores. This should be done in order to promote a regular use of such structures by the whole community and thereby may aid the maintenance of habitat connectivity for this taxa.

Acknowledgments The authors thank Brisa-Auto-Estradas de Portugal S.A. for providing the financial and logistical support for this project. Special thanks to Rui Raposo, Alexandre Pirra, Rui Casado, Joaquim Nobre, Pedro Pomar, and Gertrudes Ferro for their help in transporting and setting up the equipment. We would also like to thank all the volunteers that collaborated with us to complete the field work and view the videotapes. C. Grilo was supported by Ph.D. (SFRH/BD/10600/2002) and postdoctoral (SFRH/BPD/64205/2009) grants from the Fundação para a Ciência e Tecnologia. We also would like to thank John A. Bissonette for the valuable critical comments on the manuscript. 


\section{Appendix}

Table 5 Univariate analysis of the relationship of number of successful crossings and water depth and cover for each species

\begin{tabular}{|c|c|c|c|c|}
\hline Variables & Estimate & SE & $t$ value & Significance \\
\hline \multicolumn{5}{|l|}{ Red fox } \\
\hline Intercept & -0.829 & 0.4429 & -1.873 & 0.0821 \\
\hline Water depth & -0.428 & 0.337 & -1.271 & 0.224 \\
\hline Intercept & -0.983 & 0.439 & -1.972 & 0.069 \\
\hline Water_cover & -0.007 & 0.008 & -0.866 & 0.401 \\
\hline \multicolumn{5}{|l|}{ Stone marten } \\
\hline Intercept & 0.398 & 0.329 & 1.209 & 0.227 \\
\hline Water depth & -1.044 & 0.636 & -1.640 & 0.101 \\
\hline Intercept & 0.143 & 0.370 & 0.387 & 0.699 \\
\hline Water_cover & -0.016 & 0.007 & -2.236 & 0.025 \\
\hline \multicolumn{5}{|l|}{ Badger } \\
\hline Intercept & 1.381 & 0.297 & 4.652 & 0.000 \\
\hline Water depth & -0.469 & 0.184 & -2.551 & 0.011 \\
\hline Intercept & 1.400 & 0.295 & 4.746 & 0.000 \\
\hline Water_cover & -0.018 & 0.005 & -3.492 & 0.000 \\
\hline \multicolumn{5}{|l|}{ Otter } \\
\hline Intercept & -0.136 & 0.371 & -0.367 & 0.714 \\
\hline Water depth & 0.012 & 0.011 & 1.048 & 0.295 \\
\hline Intercept & -0.857 & -0.857 & -0.857 & 0.063 \\
\hline Water_cover & 0.017 & 0.006 & 3.160 & 0.002 \\
\hline \multicolumn{5}{|l|}{ Genet } \\
\hline Intercept & 0.212 & 0.315 & 0.673 & 0.501 \\
\hline Water depth & -2.765 & 1.348 & -2.051 & 0.040 \\
\hline Intercept & 0.056 & 0.283 & 0.197 & 0.844 \\
\hline Water_cover & -0.021 & 0.008 & -2.697 & 0.007 \\
\hline
\end{tabular}

\section{References}

Ascensão, F., \& Mira, A. (2006). Factors affecting culvert use by vertebrates along two stretches of roads in southern Portugal. Ecological Research, 22, 57-66.

Bates, D., Maechler, M., \& Bolker, B. (2011). lme4: Linear mixed-effects models using S4 classes. R package version 0.999375-42. Retrieved April 4, 2012, from http:// CRAN.R-project.org/package $=1 \mathrm{me} 4$.

Bissonette, J. A., \& Adair, W. (2007). Restoring habitat permeability to roaded landscapes with isometrically-scaled wildlife crossings. Biological Conservation, 141, 482-488.

Blanco, J. C. (1998). Mamíferos de España: Insectivoros, quirópteros, primates y carnívoros de la Península Ibérica. Baleares y Canárias. Barcelona: GeoPlaneta.
Bolker, B. M., Brooks, M. E., Clark, C. J., Geange, S. W., Poulsen, J. R., Stevens, M. H. H., et al. (2009). Generalized linear mixed models: A practical guide for ecology and evolution. Trends in Ecology \& Evolution, 24(3), 127-135.

Cain, A. T., Tuovila, V. R., Hewitt, D. G., \& Tewes, M. E. (2003). Effects of a highway and mitigation projects on bobcats in Southern Texas. Biological Conservation, 114, 189-197.

Cavalini, P., \& Lovari, S. (1994). Home range, habitat selection and activity of the red fox in a Mediterranean coastal ecotone. Acta Theriologica, 39(3), 279-287.

Clevenger, A. P., Chruszcz, B., \& Gunson, K. (2001). Drainage culverts as habitat linkages and factors affecting passage by mammals. Journal of Applied Ecology, 38, 1340-1349.

Dodd, N. L., Gagnon, J. W., Manzo, A. L., \& Schweinsburg, R. E. (2007). Video-surveillance to assess highway use by elk 
in Arizona. Journal of Wildlife Management, 71(2), 637645.

Epps, C. W., Palsbøll, P., Wehausen, J. D., Roderick, G., Ramey, I. I. R., \& McCullough, D. R. (2005). Highways block gene flow and cause a rapid decline in genetic diversity of desert bighorn sheep. Ecology Letters, 8, 1029-1038.

Fahrig, L., \& Rytwinski, T. (2009). Effects of roads on animal abundance: An empirical review and synthesis. Ecology and Society, 14(1), 21.

Forman, R., Sperling, D., Bissonette, J., Clevenger, A., Cutshall, C., Dale, V., et al. (2003). Road ecology-Science and solutions. USA: Island Press.

Grilo, C., Bissonette, J. A., \& Santos-Reis, M. (2008). Response of carnivores to existing highway culverts and underpasses: Implications for road planning and mitigation. Biodiversity and Conservation, 17, 1685-1699.

Grilo, C., Bissonette, J. A., \& Santos-Reis, M. (2009). Spatialtemporal patterns in Mediterranean carnivore casualties: Consequences for mitigation. Biological Conservation, $142,301-313$.

Guisan, A., \& Zimmermann, N. (2000). Predictive habitat distribution models in ecology. Ecological Modelling, 135, 147-186.

Hardy, A., Clevenger, A. P., Huijser, M., \& Neale, G. (2003). An overview of methods and approaches for evaluating the effectiveness of wildlife crossing structures: Emphasizing the science in applied science. In C. L. Irwin, P. Garrett, \& K. P. McDermott (Eds.), Proceedings of the international conference on ecology and transportation (pp. 319-330). Raleigh: Center for Transportation and Environment.

Hobbs, R. J. (1992). The role of corridors in conservation: Solution or bandwagon? Trends in Ecology \& Evolution, 7(11), 389-392.

Jaeger, J. A. G., Bowman, J., Brennan, J., Lenore, F., Bret, D., Bouchard, J., et al. (2005). Predicting when animal populations are at risk from roads: An interactive model of road avoidance behavior. Ecological Modelling, 185, 329-348.

Kruuk, H. (2006). Otters: Ecology, behaviour and conservation. Oxford: Oxford University Press. pp. 288.

Mata, C., Hervás, I., Herranz, J., Suárez, F., \& Malo, J. E. (2005). Complementary use by vertebrates of crossing structures along a fenced Spanish motorway. Biological Conservation, 124(3), 397-405.

Mata, C., Hervás, I., Herranz, J., Suárez, F., \& Malo, J. E. (2008). Are motorway wildlife passages worth building? Vertebrate use of road-crossing structures on a Spanish motorway. Journal of Environmental Management, 88, 407-415.

Mata, C., Hervás, I., Herranz, J., Malo, J. E., \& Francisco, S. (2009). Seasonal changes in wildlife use of motorway crossing structures and their implication for monitoring programmes. Transportation Research Part D: Transport and Environment, 14(7), 447-452.

Mateus, A. R., Grilo, C., \& Santos-Reis, M. (2011). Surveying drainage culvert use by carnivores: Sampling design and cost-benefit analyzes of track-pads vs. video-surveillance methods. Environmental Monitoring and Assessment, 181 (1), 101-109.

Matos, H., Santos, M., Palomares, F., \& Santos-Reis, M. (2009). Does riparian habitat condition influence mammalian carnivore abundance in Mediterranean ecosystems? Biodiversity and Conservation, 18, 373-386.

Ng, S. J., Dole, J., Sauvajot, R., Riley, S., \& Valone, T. (2004). Use of highway undercrossings by wildlife in southern California. Biological Conservation, 115, 499-507.

Palomares, F., \& Delibes, M. (1992). Circadian activity patterns of free-ranging large grey mongooses, Herpestes ichneumon in southwestern Spain. Journal of Mammalogy, 73, 173-177.

Palomares, F., \& Delibes, M. (1993). Key habitats for Egyptian mongooses in Doñana National Park, southwestern Spain. Journal of Applied Ecology, 30, 752-758.

Palomares, F., \& Delibes, M. (1994). Spatial-temporal ecology and behavior of European genets in southwestern Spain. Journal of Mammalogy, 75, 714-724.

Pinheiro, J., Bates, D., DebRoy, S., Sarkar, D., \& the R Development Core Team. (2012). nlme: Linear and nonlinear mixed effects models. R package version 3.1-103.

Prenda, J., \& Granado-Lorencio, C. (1996). The relative influence of riparian habitat structure and fish availability on otter Lutra lutra L. sprainting activity in a small Mediterranean catchment. Biological Conservation, 76, 9-15.

R Development Core Team (2011). R: A language and environment for statistical computing. R Foundation for Statistical Computing, Vienna, Austria. Retrieved April 4, 2012, from http://www.R-project.org/.

Riley, S. P. D., Pollinger, J. P., Sauvajot, R. M., York, E. C., Bromley, C., Fuller, T. K., et al. (2006). A southern California freeway is a physical and social barrier to gene flow in carnivores. Molecular Ecology, 15, 1733-1741.

Rodriguez, A., Crema, G., \& Delibes, M. (1996). Use of nonwildlife passages across a high speed railway by terrestrial vertebrates. Journal of Applied Ecology, 33, 1527-1540.

Rosalino, L. M., Macdonald, D. W., \& Santos-Reis, M. (2004). Spatial structure and land-cover use in a low density Mediterranean population of Eurasian badgers. Canadian Journal of Zoology, 82, 1493-1502.

Rossell, C., \& Velasco, J. M. (2001). Manual de prevenció i correcció dels impactes de les infraestrutures viàries sobre la fauna. Collecció Quaderns Dels Documents De Medi Ambient.

Row, J. R., Blouin-Demer, G., \& Weatherhead, P. J. (2007). Demographic effects of road mortality on black ratsnakes (Elaphe obsolete). Biological Conservation, 137, 117-124.

Ruiz-Olmo, J., Saavedra, D., \& Jiménez, J. (2001). Testing the surveys and visual and track censuses of Eurasian otters (Lutra lutra). The Zoological Society of London, 253, 359-369.

Santos-Reis, M., Santos, M. J., Lourenço, S., Marques, T., Pereira, I., Pinto, B., et al. (2004). Relationships between stone martens, genets and cork oak woodlands in Portugal. In D. J. Harrison \& A. K. Fuller (Eds.), Marten and fishers in human altered landscapes: An international perspective. Massachusetts: Kluwer Academic Publishers.

Stewart, P. D., Ellwood, S. A., \& Macdonald, D. W. (1997). Remote video-surveillance of wildlife-An introduction from experience with the European badger Meles meles. Mammal Review, 27, 185-204.

Taylor, B. D., \& Goldingay, R. L. (2009). Can road-crossing structures improve population viability of an urban gliding mammal? Ecology and Society, 14(2), 13. Retrieved April 2, 2012, from http://www.ecologyandsociety.org/vol14/ iss 2/art13/. 
van der Ree, R., Heinze, D., McCarthy, M., \& Mansergh, I. (2009). Wildlife tunnel enhances population viability. Ecology and Society, 14(2), 7. Retrieved April 2, 2012, from http://www.ecologyandsociety.org/vol14/iss2/art7/.

van der Ree, R., Jaeger, J. A. G., van der Grift, E., \& Clevenger, A. (2011). Effects of roads and traffic on wildlife populations and landscape function: Road ecology is moving toward larger scales. Ecological and Society, 16, 48. Retrieved April 2, 2012, from http://www.ecologyandsociety.org/vol16/iss1/ art48/.
Virgós, E. (2001). Relative value of riparian woodlands in landscapes with different forest cover for medium-sized Iberian carnivores. Biodiversity and Conservation, 10, 1039-1049.

Yanes, M., Velasco, J. M., \& Suárez, F. (1995). Permeability of roads and railways to vertebrates: The importance of culverts. Biological Conservation, 71, 217-222.

Zuur, A. F., Ieno, E. N., Walker, N. J., Saveliev, A. A., \& Smith, G. M. (2009). Mixed effects models and extensions in ecology with $R$. USA: Springer. 